\title{
Walls of Empowerment: Reading Public \\ Murals in a Kanaka Maoli Context
}

A Mārata Ketekiri Tamaira

Every wall is a gate.

- RAlPh WALdo EMERSON ${ }^{1}$

Space is not a scientific object removed from ideology and politics; it has always been political and strategic. If space has an air of neutrality and indifference with regard to its contents and thus seems to be "purely" formal, the epitome of rational abstraction, it is precisely because it has been occupied and used, and has already been the focus of past processes whose traces are not always evident on the landscape. Space has been shaped and molded from historical and natural elements, but this has been a political process. Space is political and ideological. It is a product literally filled with ideologies.

- Henri Lefebvre, "Reflections on the

Politics of SPace”

\section{WALLS}

As one of many built artifacts that occupy-indeed mold-the physical and social space of human society, walls are encoded with political and ideological meaning. In Walled States, Waning Sovereignty, Wendy Brown contended that walls constitute "visual signifiers of overwhelming human power and state capacity" (20I0, I03). Take, for example, Israel's Separation Wall, or what has come to be referred to colloquially by its detractors as the Apartheid Wall. Construction of this twenty-five-foot-high concrete barrier on the West Bank began in 2002 in an attempt by Israel to keep socalled Palestinian terrorists at bay. The wall is still in the process of being built and by the time of its completion is projected to eventually stretch

The Contemporary Pacific, Volume 29, Number I, I-36

(C) 2017 by University of Hawai'i Press 
430 miles. Another wall to consider is the United States-Mexico Border Wall. With the passing of the Secure Fence Act in 2006, the United States began constructing its own wall (although technically it is a fence), which is designed to secure the nearly 2,000-mile border between the two countries and prevent illegal immigrants from crossing over. And, of course, we cannot forget the infamous Berlin Wall of the Cold War era.

These walls, and others like them, constitute discrete discursive spaces that articulate and proclaim the dominance of one group over another through the sheer power of simply being able to mark and define space and, by extension, control human mobility. However, as impermeable as walls may seem, they are inherently unstable. This point is succinctly stated by Marc Silberman, Karen Till, and Janet Ward in their introduction to Walls, Borders, Boundaries: Spatial and Cultural Practices in Europe, "Walls are built and then fall" (20I2, I). But walls do not have to fall to be breached. For instance, their surfaces can function as a canvas for dissent and resistance by the groups they purport to contain and control. Silberman and his coeditors contended that walls (as well as borders and boundaries) are dynamic spaces that offer such groups "possibilities of survival and adaptation and the hope of transformation. They may be also understood as activist markers" $(20 \mathrm{I} 2,5)$.

In the case of the walls cited above, within years of being erected, their surfaces became semiotic slates for activist markings in the form of wall art-art that challenged and subverted the physical imposition of the partitions on the landscape and the political dominance for which they stood. By the time the Berlin Wall came down, for instance, the west face of the structure was a veritable gallery of graffiti, encoded with visual and textual statements that ranged from the romantic and the inane, to, most notably, the political. ${ }^{2}$ Frederick Baker noted that "'Overcoming the Wall by painting the Wall' was the crucial ambition of much of the art on the Wall" $(2005,34)$.

In this article, I explore how Kānaka Maoli (Native Hawaiians) overcome the ideological "wall" of US settler colonialism by transforming the physical walls of the built environment into sites of indigenous empowerment. I focus specifically on two Honolulu-based murals, the graffitiwriting mural Ola Ka Wai, Ola Ka Honua (As the Water Lives, the Earth Thrives) and the community-created Aloha 'Āina mural, to illustrate how Kānaka Maoli use the surface of urban and temporary walls as semiotic slates to both affirm Kanaka Maoli sovereignty and contest US colonialism. In a broader sense, the two murals I consider run parallel to the larger 
network of wall art culture in Hawai'i-ranging from the clandestine practice of tagging to the flamboyant showmanship of street art-which is always already embedded in a philosophy of resistance, agency, and self-representation. According to graffiti scholar Cedar Lewisohn, graffiti gives "people from marginalised areas of society [in particular] the opportunity to 'be somebody'... . You could literally make your mark in the world" (2008, 43).

For Kānaka Maoli, as for other Native communities throughout the Pacific (and indeed the globe), the ability to make their "mark in the world" through the arts has been a crucial means through which to revive and celebrate their histories and cultural traditions as well as assert grievances relating to the colonization of their homelands. Murals have functioned as a valuable mode of representation in particular because they are squarely located in the visual panorama of everyday life, appearing on concrete motorway barriers and underpasses and construction fences, on the walls of industrial-commercial neighborhoods, schools, bus stops, and so forth. The general public is hard-pressed to avoid them, which means the messages they carry are able to reach a wider audience in contrast to art that is ensconced within a gallery or museum.

It should come as no surprise, then, that public murals have become a prevalent feature across the Pacific region as artists and communities seek ways to articulate their ongoing presence in their homelands. For example, the Welcome to Redfern mural on the wall of a Victorian-era building located in the Redfern neighborhood of Sydney stands as a lasting tribute to local Aboriginal history and the ongoing presence of Aboriginal communities in the area. Internationally recognized Aboriginal artist Reko Rennie led the mural project and was joined by eight young locally based Aboriginal artists. Welcome to Redfern is rendered in a tricolor scheme of black, yellow, and red-the colors that have become representative of the Aboriginal people of Australia. Further, the mural pays tribute to Aboriginal leadership by rendering images of key historical figures, such as Pemulwuy, an eighteenth-century clan warrior who led resistance efforts against white colonists. In Aotearoa/New Zealand in 201 5, Ngāi Tūhoe activist/artist Tame Iti teamed up with Pākehā street artist Owen Dippie to produce Ma Mua a Muri Ka Tika (Learn from the Past to Prepare for the Future). ${ }^{3}$ The focal feature of the mural is the larger-than-life image of Hokimoana Tawa, a respected kuia (elder woman) of the Tühoe tribe. Located in the small Bay of Plenty township of Tāneatua-considered the gateway to Te Urewera, the ancestral homeland of the Tühoe people-the 
mural is an empowering counterpoint to the "Tūhoe Terror Raids" of 2007 and provides, as Iti stated, "a way for Ngāi Tūhoe to build a nation and bring the iwi [tribe] together" (Kaire-Melbourne 2015).

While these two examples garnered a great deal of media attention, many such artistic interventions on urban walls occur without fanfare in places across the Pacific, including Guam. Here, one mural features a Chamorro warrior who stands vigil in front of an ocean scene of fish, flora, and indigenous sailing vessels. The text on the wall reads in Chamorro language: "Prutehi yan Difendi" (Protect and Defend). Another written message reads in English: "Don't Dredge My Home." Importantly, the mural was produced by members of We Are Guåhan, an indigenous Chamorro group dedicated to protecting Guam's lands, ocean, and natural resources, in particular from the destructive activities of the US Department of Defense, which uses the waters surrounding the wider Marianas Islands as its largest training range.

In this article, I link the Australia, New Zealand, and Guam muralsas well as other such aesthetic and ethical endeavors-to what Tuscarora scholar Jolene Rickard has termed "visual sovereignty," the contours of which emerged in her 1995 article "Sovereignty: A Line in the Sand." Rickard advocated for a more comprehensive reading of indigenous sovereignty that expands beyond the political and includes aesthetic articulations. Central to her argument is the idea that, "as part of an ongoing strategy for survival, the work of indigenous artists needs to be understood through the clarifying lens of sovereignty and self-determination" (Rickard $1995,5 \mathrm{I})$. In a general way, a visual sovereignty paradigm entails the principle that Native visual representations operate as declarations of unrelinquished sovereignty and are inextricably tied to political and cultural acts of resistance in the face of advancing colonialism. In the specific case of Kanaka Maoli art production in Hawai' i, I read visual sovereignty as an aesthetic strategy through which Kanaka Maoli artists articulate an indigenous-centered perspective that conveys Native epistemologies, ongoing political struggles, and ancestral connection to place. An examination of contemporary Kanaka Maoli art using visual sovereignty has not yet been advanced in the Hawai'i context, but a growing body of scholarship by Native American and First Nations academics and art practitioners indicates the indispensability of opening up a discussion that attends to Kanaka Maoli visual culture as an extension of indigenous sovereignty.

Some examples of this innovative and empowering work includes the 2006 publication Our People, Our Land, Our Images: International Indig- 
enous Photographers, by artist Hulleah J Tsinhnahjinnie and art historian and curator Veronica Passalacqua. The book features the creative production of twenty-six indigenous photographers from all over the world, including the United States, Canada, Peru, Aotearoa, and Palestine, using the overarching theme of visual sovereignty as a theoretical foundation for reading indigenous photography. Visual sovereignty as a paradigmatic tool surfaced even more prominently three years later at the 2009 "Visual Sovereignty: International Indigenous Photography" conference (of which Rickard was one of the organizers). Held at the University of California, Davis, the conference culminated in a collaborative exhibition at the university's C N Gorman Museum titled Visual Sovereignty: International Indigenous Photography Gathering. Over the last several years, the term has gained traction in indigenous film studies scholarship in particular, including Reservation Reelism: Redfacing, Visual Sovereignty, and Representations of Native Americans in Film (2010), by Michelle Raheja, who used visual sovereignty as a framework for examining Native American engagements in the film industry as filmmakers and as actors, and Sovereign Screens: Aboriginal Media on the Canadian West Coast (2013), by Kristen L Dowell. The struggle for sovereignty takes place on many fronts, certainly the political but also the intellectual, cultural, and the artistic.

\section{Public Murals in a Kanaka Maoli Context}

Reading the "Writing" on the Walls: Sovereign Flows in Ola Ka Wai, Ola Ka Honua

I began this article with a discussion about walls, but in truth I am not so much interested in walls as I am in the visual statements that are on them and the significance of those statements in relation to expressions of Kanaka Maoli visual sovereignty. In Hawai'i, public walls-themselves entrenched in uneven relations of power, specifically as it applies to the relentless drive for development in the Islands whereby new walls are erected on a daily basis-function as sites for creative production that is at once affirming of Native Hawaiian sovereignty and resistant to ongoing colonialism. In "Missionary Graveyard," Haunani-Kay Trask wrote, "graveyard Hawai'i Nei: / coffin buildings, concrete parking lots, / maggot freeways / smell of death / smeared across the land / killing in the heart" (1994, I3). Trask's poem can be read as a keening lamentation for the loss of Hawaiian lands and waterways that have disappeared under tourism, overpopulation through the steady flow of immigrants to Hawai'i's 
shores, and, most prominently, development. Of all the places in Hawai' $i$, Honolulu is perhaps the most emblematic example of this "killing in the heart." Encompassing the tourist centers of Waikīki and Ala Moana, Honolulu is the proverbial "concrete jungle" of the Islands, populated by towering high-rises and permeated by roads that are perpetually congested with traffic.

Kokea Street in the Kalihi-Pālama district of Honolulu is a striking example of the city's industrial-urban sprawl with its rows of warehouses, retail stores, and low-income, low-rise apartments. The only evidence of nature in this dry, asphalt-laden neighborhood are the trees that were planted in a vain effort to beautify the area, a narrow drainage canal of brown water, and a muddy bank that is littered with old tires, plastic bottles and bags, and other discarded trash. Presented with this scene of environmental degradation and industrial pollution, one would be forgiven for not knowing that the area at one time was populated by at least forty-five lo'i kalo (irrigated terraces planted with taro), all of them fed by the once-healthy and free-flowing Kapālama Stream. Kokea Street seems an unlikely place to find visionary artistic enterprise, yet just past a packed parking lot and a large expanse of cleared land marked for development, a wall of vibrant artistry looms into view.

Completed in 20II and measuring two stories high and almost two hundred feet long, the graffiti writing mural Ola Ka Wai, Ola Ka Honua (As the Water Lives, the Earth Thrives) constitutes the third mural in the ten-mural WaterWrites series (figure I). Organized under the auspices of the Estria Foundation, WaterWrites is a community-building, social-justice initiative that addresses, through the medium of public art-specifically graffiti writing-environmental issues relating to water sustainability in cities throughout the globe. ${ }^{4} \mathrm{Ola} \mathrm{Ka}$ Wai, Ola Ka Honua was a collaborative effort that involved a multicultural cohort of twenty graffiti writers in total,, 5 including Kanaka Maoli artists Estria Miyashiro and John "Prime" Hina, who coordinated the project. The mural took just over one month to complete and required 350 cans of spray paint and fifty-five gallons of house paint.

In Hawai'i, water has long been the subject of intense and ongoing debate. Beginning in the mid-nineteenth century, streams and rivers across the Islands were diverted from their natural courses, initially to feed the sugar plantations and later to supply emerging suburban communities, businesses, and resorts. Today, despite its status as a public trust resource that is protectable under the Hawai'i State Constitution and the state's 
Water Code, water remains under threat. ${ }^{6}$ On the island of O'ahu alone, the Waiāhole Ditch system diverts up to I 2.7 million gallons of water per day to the drier leeward side to provide not only potable water for human consumption but also non-potable water for golf course irrigation, corporate agriculture, housing and resort development, and recreational landscaping. As Earthjustice attorney Kapua'ala Sproat noted, "Despite laws on the books, large companies-former plantations included-continue to ... treat public water resources as their private property. Our management system has been reduced to might makes right" (20I0, I92). Isaac Moriwake commented further on the negative impact of water diversion on the environment and Native cultural practices:

[The] long period of abuse ... has devastated the biological and the ecological integrity of the streams but also the cultural system, this native Hawaiian culture that depends on free-flowing streams for the stream life that the stream flows feed, for the near shore marine life and resources that the freshwater entering the streams sustain. Stream flow is also essential for cultivating kalo or taro, which is the native Hawaiian staple and really the symbol of native Hawaiian culture. All these resources over the years declined because of these large-scale plantation diversions. (Moriwake and Sproat 20II)

Ola Ka Wai, Ola Ka Honua presents an empowering vision of how things could be if the natural flow of the waters was restored and responsible

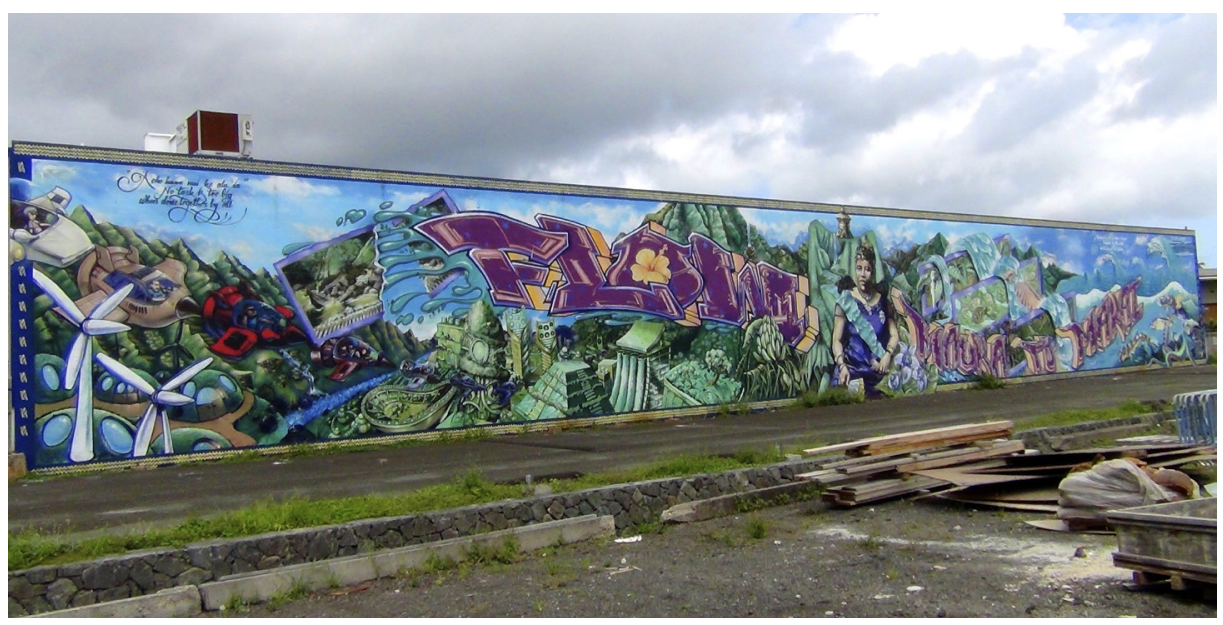

Figure i Ola Ka Wai, Ola Ka Honua (As the Water Lives, the Earth Thrives), by Estria Miyashiro, John "Prime" Hina, and others (20II). Photograph by A Mārata Ketekiri Tamaira, 20I4. 
Native-based stewardship of the 'aina (land) was practiced across the Islands.

The brightly painted mural comprises three principal sections. On the right-hand side, the homeostatic system of a traditional ahupua'a is shown, each resource zone-kalo terrace, fishpond, and dryland agricultural field-being represented in discrete visual "stills" that are cleverly consolidated into the overall composition. The water from the mountains gushes through the different zones before emptying into the ocean. Native marine fauna from the various aquatic habitats of stream, shoreline, and deep water are also depicted, such as 'o'opu (gobie), 'oama (goatfish), he'e (octopus), and honu (turtle).

This representation of past land and water stewardship is complemented on the left-hand side of the mural with images of what an ahupua'a of the future might look like. A bird's-eye view of a futuristic Honolulu reveals solar panel-roofed buildings, the walls of which are covered with living plants. Rather than dominate the skyline in a dreary hue of concrete grey, these verdant green mounds crouch unobtrusively on the landscape. The buildings share the space with present-day "green" technologies, such as wind and water turbines and a catchment water system that feeds a communal garden. In a more whimsical imaging of the future, the artists also include anti-gravitational vehicles, which are operated by their human pilots.

Present-day realities are not precluded in this affirmative vision of environmentally balanced, self-sustainable living. Above the cityscape, 'İao Stream-one of four streams on Maui that have for over a century been diverted for commercial agricultural interests-is represented in the same kind of "still" used to frame the various ahupua'a zones. Since 2003, Native Hawaiians have been engaged in a legal battle to have Nā Wai 'Ehā (The Four Streams) of Maui, which includes 'Īao Stream, restored and returned to the people. ${ }^{7}$ In the visual representation of 'Īao Stream, the grill through which the water is diverted is clearly apparent. However, what is equally unmistakable is the torrent of water that courses unimpeded through a giant tear in the image. The message is that these waters will not be held back, despite the political tactics of powerful corporate enterprises to control their flow. The words "Flow Mauka to Makai" ("Mountain to Sea") that stream across the length of the mural function as a cohesive element that ties the entire composition together. Spoken out loud, the words are like a mantra willing the waters to once again flow unimpeded from the top of the mountains to the ocean. Hawaiian cultural 
values of cooperation and collective well-being are also invoked in the written 'olelo no'eau (Hawaiian proverbs) located on the left- and righthand side of the mural, respectively:

'A'ohe hana nui ke alu 'ia

(No task is too big when done together by all)

Mōhala i ka wai ka maka o ka pua.

(Unfolded by the water are the faces of the flowers) ${ }^{8}$

The second proverb cited here is important to think about in terms of uncovering other present-day realities that deserve critical attention. The "faces of the flowers" may be read as a metaphor for the wider community, which blooms or "unfolds" when the health of the streams is maintained. However, the use of such a large volume of spray paint and house paint (as indicated above) to create Ola Ka Wai, Ola Ka Honua patently contradicts this vision of environmental stewardship and well-being. Paint, after all, tends to be highly toxic to the environment, especially if it enters precious waterways. Hina is quick to acknowledge that for indigenous graffiti writers like himself and Miyashiro, the principal materials of their practice-paint and aerosol cans-pose an ethical dilemma. One way the artists actively sought to mitigate potential harm to the environment during the project was to use water-based and charcoal-based spray paint, which is free of highly toxic substances like xylene and toluene. Further, the spray and paint cans used for the project were creatively repurposed or "upcycled." That is, as Hina stated, "[we] turned them into artwork from lampshades to planters to party centerpieces and [gave] them as gifts with the idea of keeping the cans out of our landfills" (pers comm, May 20I6).

Despite these mindful measures, there remains an uneasy tension between conceptualizing a mural like Ola Ka Wai, Ola Ka Honua-with its message to mâlama 'äina (care for the land and, by extension, the wider environment) - and the potential harmful process by which such a project is executed. Hina admits without reservation that it is a struggle that demands careful and responsible consideration. While the limits of space prevent me from expanding further on the subject, it is clear that future scholarship that examines the nexus between Kanaka Maoli graffiti writing and environmentally sustainable practice would be of tremendous value to understanding the deeper complexities and nuances of this art form in an indigenous context where land and resources are central concerns. 
Native sovereignty is a principal theme in the mural, and it is most conspicuously cited in the larger-than-life figure of Queen Lili'uokalani, who is stationed at the center of the mural, between the past and the future. The image is based on a black-and-white photograph taken of the queen during her reign (I89I-I893). In the photograph, she is shown seated on her royal throne, over which is draped an 'ahu'ula (feather cloak). In the mural, the cloak is artistically reconceptualized as a lush valley comprising Crown lands-lands that were confiscated during the I 893 overthrowthrough which surges a rushing stream that cascades over the queen's right shoulder and across her heart to become her royal sash. Miyashiro noted that the orientation of the royal sash over the queen's heart was not only in keeping with the photographic source but also strategically positioned to indicate that "she's still pouring her heart out to help us" (in Estria Foundation 20I2).

The deliberate inclusion of Queen Lili'uokalani as the central figure in Ola Ka Wai, Ola Ka Honua may best be understood in the context of what Sherry B Ortner described as a grammar of "summarizing symbols." As Ortner wrote: "Summarizing symbols are primarily objects of attention and cultural respect; they synthesize or 'collapse' complex experience, and relate the respondent to the grounds of the system as a whole. They include most importantly sacred symbols in the traditional sense" (I973, I344).

In the case of the mural, the central symbol of attention and cultural respect is the personage of the Hawaiian Kingdom's last ruling monarch. Queen Lili'uokalani's image bears critical meaning for Kānaka Maoli who revere her as an icon of resistance and unrelinquished Native sovereignty. For instance, during sovereignty marches and protests, her image is often used on flyers and posters along with her famous motto "Onipa'a," a Hawaiian term meaning steadfast, firm, and resolute, and which was used by Queen Lili'uokalani to fortify her people when the Hawaiian Kingdom was forcibly and illegally overthrown by a group of American businessmen in 1893 . For Hina and Miyashiro, the emphasis on the queen is reflective of their own political conviction that the Hawaiian Kingdom was never terminated and remains in existence to the current day. From Miyashiro's perspective, the image of Lili'uokalani "reaffirms for people that are looking at it: I am Hawaiian and we are a Kingdom" (interview with artist, Aug 2013). Thus, the queen's image functions as a contemporary rallying point for the affirmation of sovereign Hawaiian identity, a symbolic counterpart to the more concrete claims that are being made by Kānaka Maoli in the areas of law and politics. ${ }^{9}$ 
According to Ortner, one of the key characteristics of a summarizing symbol is "its focusing power, its drawing-together, intensifying, catalyzing impact upon the respondent" (1973, I342). As Hina and Miyashiro were to discover, the visual representation of Lili'uokalani catalyzed the public in unexpected but profound ways. Prime relayed his encounter with a twelve-year old girl who shared her own story with him:

She [the young girl] said, "I just wanna tell you that ... I brought my grandmother by." I was like, oh that's good. And she said, "No, but my grandmother never leaves the house. But when I went home I told my grandmother about the mural and about the queen. She got off her rocking chair and she walked and that's the first time I seen my grandmother walk. And she cried for the queen." (Interview with artist, 2I Aug 20I3)

As a symbolic display of Native sovereignty, the mural was further enhanced at the unveiling-which took place 7 July 2007 and included a blessing, a hula performance, and an appearance by singer-songwriter Palani Vaughan-by the presence of the Hawaiian Royal Guard, who were stationed in front of the queen's image for the entire event, despite the intense summertime heat (figure 2). For Miyashiro, it was a lesson in how seriously Kānaka Maoli viewed the mural and how the queen continues to resonate as a symbol of Native pride and identity:

The Royal Guard stood in front in . . f full uniform and they're sweating... right? And we're trying to drive this lift in front [of them] to unveil her. We had this big tarp covering her. And so we're like, "Oh, excuse me bruddah." And they're like, "Oh, I cannot move. You gotta go around me." And I realized, they think of this [image] as equally important as the queen herself. (Interview with artist, Aug 2013)

The unveiling of the mural not only revealed the strong feelings of fidelity that Kānaka Maoli continue to have for their sovereign, but it also exposed a resolute resistance to US colonialism. In a show of indigenous national pride, Palani Vaughan performed the Hawaiian patriotic song "Kaulana Nā Pua" (Famous Are the Flowers). Written in the wake of the I 893 overthrow, ${ }^{10}$ the song was a "statement of rebellion" that pledged loyalty to the queen and denounced the schemes of the haole (white) annexationists (Nordyke and Noyes I993, 27). In a photograph Hina shared with me, he, Miyashiro, and Vaughan are shown standing in front of the queen's image during the unveiling celebrations. Flanking the trio are two standard bearers holding flag banners that read, "HAWAIIAN INDEPENDENCE" 


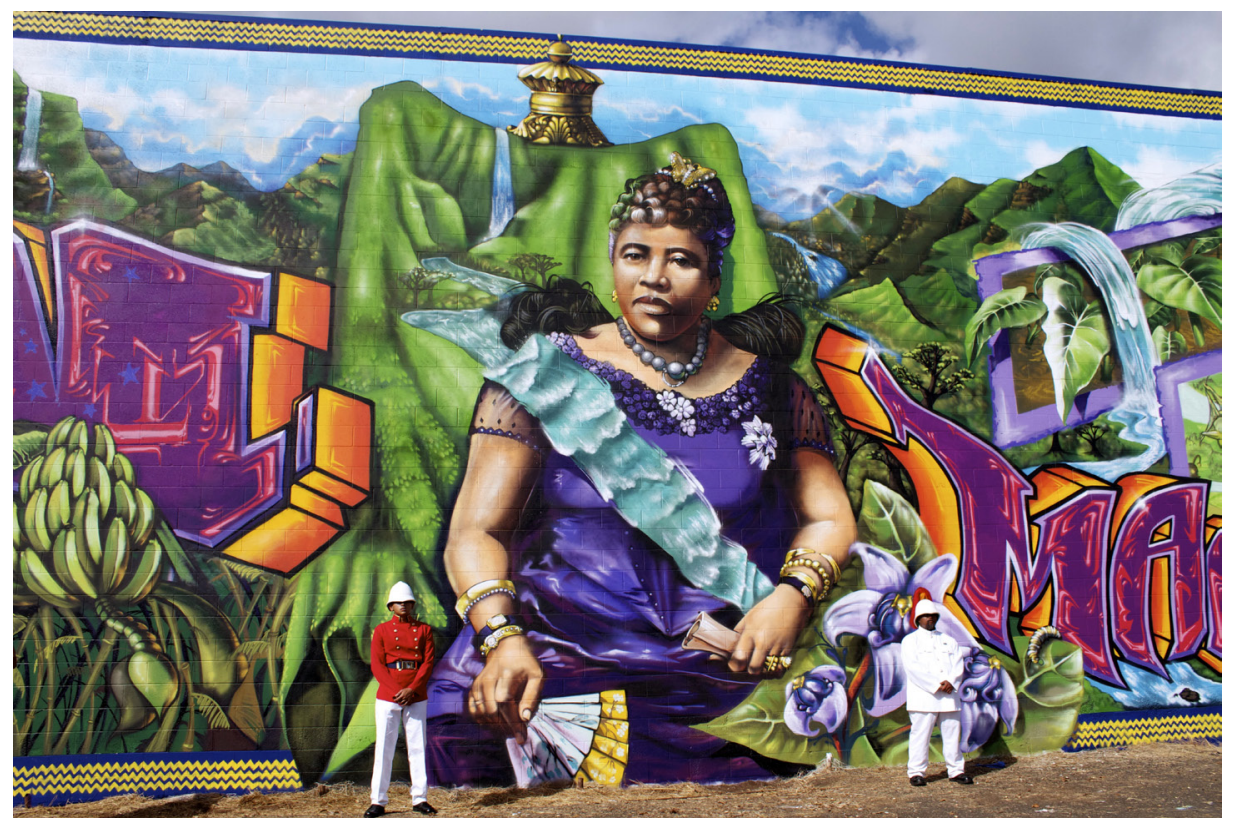

FIGURE 2 Royal Hawaiian Guards keeping watch over Queen Lili'uokalani's image. Photograph by Paula Ota, 20I I; reproduced with the photographer's permission.

(figure 3). The photograph illustrates in a profound way the intersection between Native art and politics in Hawai' $i$.

As I stated earlier, graffiti murals are highly visible and therefore highly accessible, able to reach a much larger number of people than the creative productions that feature in galleries and museums. Noted Miyashiro:

When we paint outdoors, hundreds of thousands of people see it in a week. Millions of people see it in a year. You know, academics talk about taking the art—and not just visual art, but dance and performance, and what have youtaking all of those art forms out of the institutions and going into the community where the people are. Because they can't get the people through the doors [of the galleries]. So when you paint outdoors, you can't help it. You turn the corner, BAM! It's there. (Interview with artist, Aug 20I3)

Hina and Miyashiro stressed the importance of being inclusive of both Kānaka Maoli and non-Kānaka Maoli in their messaging in order to generate a collective sense of kuleana (responsibility), particularly as it relates to settlers and visitors recognizing the true value of Hawai' $i$ as a Native 


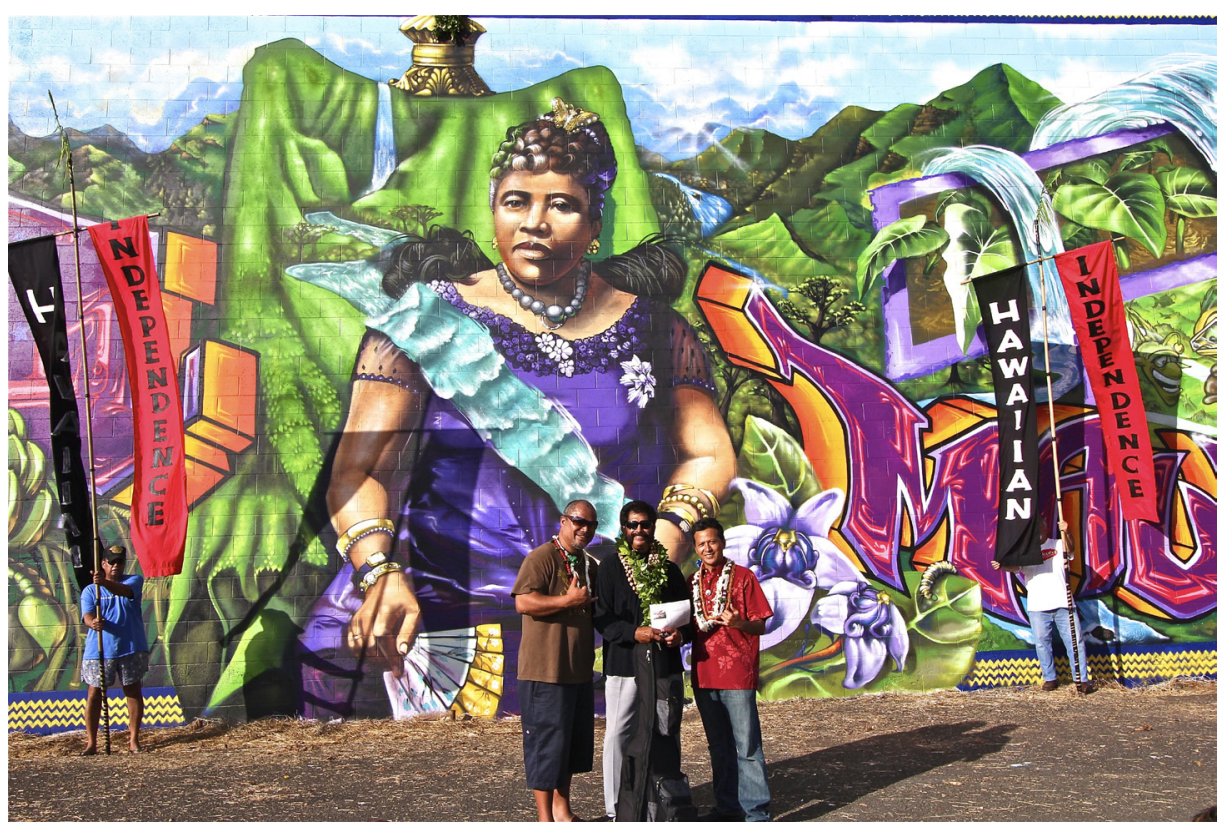

Figure 3 John "Prime" Hina (left), Palani Vaughan (middle), and Estria Miyashiro (right) stand in front of Ola Ka Wai, Ola Ka Honua during the mural's unveiling ceremony. Photograph by Paula Ota, 20I I; reproduced with the photographer's permission.

homeland rather than as a possession of empire to be exploited. Hawaiian social, economic, environmental, and political issues cannot simply be limited to the purview of Hawaiians but are of concern to everyone living in the Islands.

Ola Ka Wai, Ola Ka Honua serves as a testament to the strategic use of art by Kanaka Maoli practitioners in their bid not only to uplift their own people with visual affirmations of Native sovereignty but to also hail settlers as part of a broader call to collective responsibility and action. I argue that this form of inclusive aesthetic engagement could prove to be the most virile antidote to unseating settler ignorance in Hawai' $i$. Indeed, it may succeed where political rallies and other high-profile sovereignty initiatives have been unsuccessful.

\section{The Aloha 'Āina Mural: Protecting a Sacred Mountain}

Two thousand eleven marked the inaugural year of the Ka Leo Arts Festival, an event sponsored by the University of Hawai'i at Mānoa (UHM) 
student-run newspaper Ka Leo o Hawai'i (The Voice of Hawai $i$ ). The now-annual festival was part of the all-American, collegial celebrations of Homecoming Week and included a vibrant program aimed at showcasing the artistic and creative talents of UHM students. As part of the 2013 festivities, $\mathrm{Ka}$ Leo issued a call for student artists to create murals on one of many temporary construction walls that had been erected around campus as part of a major renovation project at the university. The application process to participate was straightforward: candidates were asked to submit a statement of purpose and an accompanying draft of the proposed composition. Community muralist Haley Kailiehu, a doctoral candidate in the Uнм College of Education and a member of HauMĀNA-a proHawaiian independence student group at the University of Hawai'i-submitted an application, citing HauMĀNA's intent to use the wall to celebrate the mountain Mauna-a-Wākea (Mountain of Wākea). ${ }^{11}$ Located on the island of Hawai'i, Mauna-a-Wākea is the highest mountain in the Hawaiian Archipelago and is revered by Kānaka Maoli as an ancestor.

The proposal was approved, and on the weekend of $\mathrm{I}_{2}-\mathrm{I}_{3}$ October 20I3, Native and non-Native UHM students and faculty, as well as members of the broader community-including kūpuna (elder generation) and keiki (children) - converged at the designated wall to begin sketching out and painting the Aloha 'Áina mural. The approximately eight-foot-high by twenty-foot-wide mural is a visual retelling of one of many traditional mo'olelo (stories/histories) relating to Mauna-a-Wākea (figure 4). In the painted scene-made up of earthy hues of brown, crimson, purple, lavender, and green-the deities Wākea (Sky Father), Papahānaumoku (Earth Mother), and Ho'ohokūkalani (Star Maker) stand out as central figures in the foreground.

Positioned at the bottom-center of the mural, Wākea and Papahānaumoku are shown facing each other in an attitude of connubial affection. Their daughter Ho'ohokūkalani stands beside her father, holding in her arms her second-born son, Hāloa. The child-who in Hawaiian oral tradition is recognized as the founding ancestor of the Hawaiian people-was created from the union between Ho'ohokūkalani and Wākea. Kalo, a root crop that is the staple food of Kānaka Maoli and revered as an elder sibling by them, is a prominent motif in the mural, its green, heart-shaped leaves populating the middle ground to form a metaphorical lo' $i$ (irrigated terrace). In the piko (center) of the largest kalo, Lake Waiau-the sacred lake located on Mauna-a-Wākea-is depicted in hues of red and blue. Its fluid contents spill out and trickle down to anoint Wākea and Papahānaumoku below. 


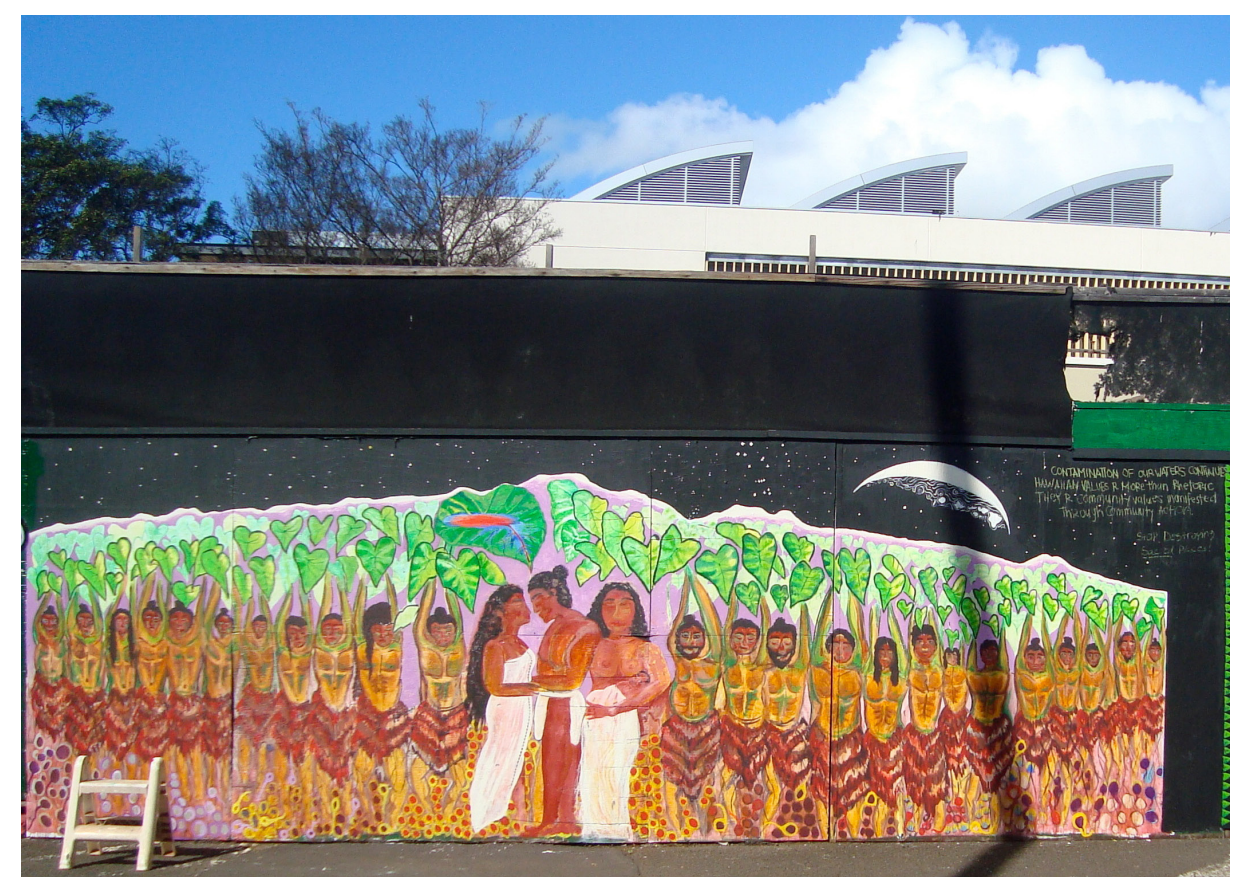

Figure 4 Aloha 'Āina mural, University of Hawai'i at Mānoa. Photograph by A Mārata Tamaira, 20I3.

As one takes a step back from the mural, the "sedimentary" formation of its design becomes easily apparent. At the bottom of the piece, numerous painted rocks make up the first sedimentary layer-the rocks being perhaps denotative of the volcanic scoria found on Mauna-a-Wākea. Some of the rocks possess what look like flagella, visually transforming them into male reproductive cells. The symbolism is compelling: what at once appears to be a scattering of assorted rocks now evolves into a quivering, converging cluster of semen, with the "tail-less" rocks representing ova. The teeming of so many reproductive cells announces the potent fecundity of Kānaka Maoli. This is underscored by the row of human figures-men and women - that makes up the second layer of the mural. The figures-past, present, and future generations of Kānaka Maoli-are shown holding up the cultivated terrace of kalo above them, which as I interpret it signals the kuleana Kānaka Maoli have to mālama 'āina (care for the land) and through such reciprocal action thrive into the future.

The mountain itself, Mauna-a-Wākea, looms in the background and makes up the fourth visual layer. Rendered in a shade of soft lavender with 
its summit capped in white, the mountain functions as a receptacle that encompasses the discrete but related strata of rocks/cells, people, kalo, and gods in a unified matrix. It is as if all of these visual constituents make up the very layers of the mountain itself. Above Mauna-a-Wākea, a celestial network of stars and the moon light up the night sky-the sky being the proverbial realm of Wākea. In one section in particular, just above the second summit of the mountain, the muralists included a cluster of stars that represents the Makali $i$ constellation (the Pleiades or Seven Sisters), a significant star formation in Hawaiian cosmological tradition. To the far right of the night sky is a crescent moon, shown in the phase identified in the Hawaiian lunar calendar as Hoaka. As Kailiehu explained to me, in ancient times Hawaiians would often refer to the shape of their Island archipelago in metaphorical terms as resembling this phase (pers comm, Oct 20I3).

While the pictorial aspects of the mural clearly affirm the ongoing cultural and genealogical connections between Kānaka Maoli and Mauna-aWākea, in a more critical way the mural functioned as a political forum through which Kanaka Maoli grievances concerning the mountain could be made. For decades, Kānaka Maoli have been engaged in the struggle to protect Mauna-a-Wākea from what they see is the destruction and desecration of their ancestor through its development as an astronomy facility. There are currently thirteen telescopes on the mountain, which are owned and operated by numerous corporations and universities from countries all over the globe. ${ }^{12}$ Writing to the editor of the Minnesota Daily in 2002, Kealoha Pisciotta-a Hawaiian cultural practitioner who worked for the observatories as a telescope systems specialist for twelve years-articulated the problem:

The upper region of Mauna Kea is considered the highest and most sacred temple of Native Hawaiians, it is the burial ground of our highest born and most sacred ancestors.... Corporations pay only \$I per year in lease rent for the use of our land. They introduce hundreds of thousands of gallons of human waste into the principal aquifer of our island and use hazardous materials such as elemental mercury. . . . Universit[ies] push their developments . . in the name of "education and research" [but] the technology developed on the telescopes is used to attract military and corporate contracts worth millions of dollars (quoted in LaDuke 2005, 30-3I).

In addition, the construction and operation of the observatories is a threat to some ninety-three culturally significant sites known to exist on the 
mountain (including ancestral burials) and puts numerous species of flora and fauna living on its slopes-some of them endangered-at risk. Further, the presence of the telescopes has impeded Hawaiians from practicing their religious rituals on the mountain. ${ }^{13}$ The controversy surrounding Mauna-a-Wākea is, as Manulani Aluli Meyer insightfully observed, "a perfect example of clashing cosmologies" (in Puhipau and Lander 2006).

For the members of HauMĀNA involved in organizing the Aloha 'Áina mural, the "clash" involved their own university. Beginning in the I96os, the University of Hawai'i has been the leading force behind Mauna-aWākea being developed into the Mauna Kea Science Reserve. The reserve comprises II, 288 acres of seized Hawaiian national lands (all the lands on the summit from II,000 feet up), which are managed by the Hawai' $i$ State Board of Land and Natural Resources and leased to the University of Hawai' $i$. The university in turn subleases the land (as noted by Pisciotta, at the nominal fee of \$I per year) to other universities, corporations, and foreign governments for development.

The university's recent decision to lease out eight acres to an international consortium of universities and corporations for the planned construction of the Thirty Meter Telescope has generated the latest chain of opposition from Kānaka Maoli. At eighteen stories high and equipped with a thirty-meter lens, the Thirty Meter Telescope would surpass the capabilities of even the Hubble Space Telescope. But for many Kānaka Maoli, such advances in astronomy would entail a violation of their own connection to the land and the wider environment to which they are genealogically related. In a June 2013 article in the Big Island Weekly, Pisciotta is quoted as stating, "If we say yes to more development, we are saying yes to the desecration of our temple and our ancestors, yes to the desecration of our waters, and yes to the possible extinction of life itself" (Winpenny 2013).

As a student-led group committed to upholding the principle of aloha no ka 'āina (love for the land), HauMĀNA used the Aloha 'Āina mural as a site of aesthetic resistance to challenge the university's continued role in what they see as the desecration of Mauna-a-Wākea and to raise awareness about the most recent threat to the mountain. They also drew attention to the insincerity behind the university's purporting in its 20II-20I5 Strategic Plan to be a "Hawaiian Place of Learning" when its policies relating to Mauna-a-Wākea are in clear disregard of Hawaiian values concerning land and sacred places (University of Hawai'i nd). As lead artist for the project, Kailiehu strategically used black paint to create a "chalkboard" 
space next to and above the mural "to allow the audience to interact with [the] art piece and leave messages" (cover letter in author's files [ 15 Oct 20I3]). The black chalkboard also enabled Kailiehu and the other members of HauMĀNA to articulate their own political position. That position was clearly stated in the far left-hand corner of the mural (figure 5):

UH cannot be a Hawaiian place of learning

while leading the desecration of Mauna a Wakea.

Hey uH .... Be accountable

Be a Hawaiian place of learning ...

Stand with the people...

Stop the desecration...

Stop the Thirty Meter Telescope!

Members of the Uнм Marianas Club also joined in solidarity with Kānaka Maoli, chalking their own sentiments on the wall (see figure 5):

Hita i taotao Marianas [the people of Marianas] stand in solidarity with Kanaka Maoli for the protection of our sacred lands. and

Pacific Islanders stand together ...

Marshall Islanders stand with Kānaka Maoli.

On the far right, another message read:

Contamination of our waters continues. Hawaiian values $\mathrm{R}$ more than rhetoric. They $\mathrm{R}$ community values manifested through community action.

When I arrived on the final day of the project to help paint, I learned of the first rumblings of institutional censure. Kailiehu informed me that the day before, $\mathrm{Ka}$ Leo Marketing Director Rob Reilly had approached her and other members of HauMĀNA to inform them that the UHM administration did not approve of the mural's message, specifically as it related to the political content written in chalk. The group was given the option to either cover up the text themselves or risk having it forcibly removed by $\mathrm{Ka}$ Leo employees. Despite the threat of censorship, HauMĀNA refused to conceal the written sentiments and instead continued painting.

The weather forecast for the weekend of $\mathrm{I}_{2}-\mathrm{I} 33$ October was for thunderstorms and rain, but during the Sunday afternoon that I had the opportunity to lend my own brushstrokes to the mural, the dark cumulus plumes in the distance managed to remain at bay. I joined with a cohort of other 


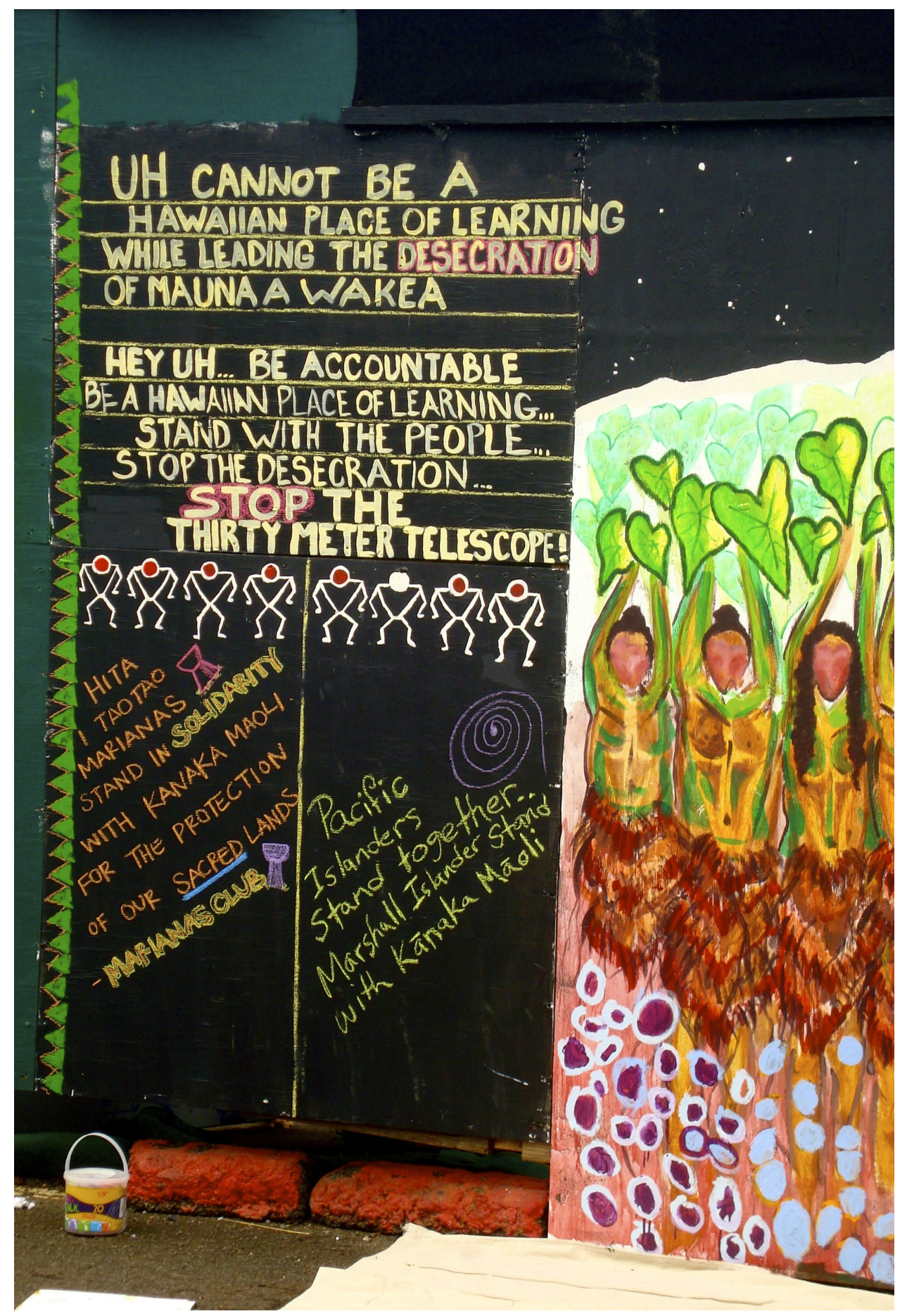

Figure 5 Detail of Aloha 'Āina mural. Photograph by A Mārata Tamaira, 2013 . 
painters and together we jostled for space at the face of the mural, each of us intent on giving visual life to the wall in front. The collegial hum of voices in quiet conversation was punctuated every now and then by bursts of laughter and convivial greetings of welcome as people throughout the day continued to arrive to help. But mostly the mood was one of quiet contemplation and focus. A large Hawaiian flag stood next to a table that bore on it a petition calling for the cessation of development on Mauna-aWākea. I added my name to the long list of signatures that had been collected over the past two days. The flag rippled in the breeze and served as a constant and powerful reminder of the sovereign purpose for which the artistic gathering had been convened: to oppose the ongoing destruction of Native lands in Hawai' $i$. By the time I departed, the mural was almost complete. A couple of hours later, as the final touches were being made to the piece, the first claps of thunder began to resound. Not long after that the sky opened up and emptied its life-giving contents onto the land.

When the mural organizers arrived at the wall the next morning, they discovered the written expressions of sovereignty and solidarity gone. But it was not the downpour from the previous day that had removed them. Rather, individuals working for $\mathrm{Ka}$ Leo had covered them up with green paint, replacing the words with an advertisement for the Ka Leo Arts Festival that read "\#Ka Leo Fest." The rest of the mural had been left intact, but all trace of the political text had been erased. The response by Kānaka Maoli was swift. HauMĀNA shifted their activism from the mural wall to their Facebook wall, where they issued a call to action. Part of it read:

\section{ACTION ALERT!}

What: Aloha 'Āina Rally at Mauna a Wākea mural.

When and Where: Tomorrow, Tuesday, October I 5 th. Io am at the Mauna a Wākea mural [uнм Campus Center construction boards bordering the Art Building]

Why: To tell Ka Leo and uH that they cannot censor Kanaka Maoli student voice!

Despite receiving less than twenty-four hours' notice, the next day an estimated three hundred people - many carrying homemade signs bearing slogans such as "Censorship is Desecration," "UH Censoring Native Hawaiian Voices," and "Protect Sacred 'Āina"-converged at the Aloha 'Āina mural to protest the blatant censorship of Kanaka Maoli voices. Gathered 
together in a wide circle with hands linked, the crowd was led in an oli (chant) to symbolically open up the space for critical thought and discussion. Composed as a supplication to the gods for wisdom, the chant read:

E hō mai ka 'ike mai luna mai ē

(Give forth knowledge from above)

'O nā mea huna no'eau o nā mele ē

(The hidden secrets of the chants)

E hō mai, e hō mai, e hō mai è

(Give forth, give forth, oh give forth)

With the protocol completed, a number of the organizers offered their own informed perspectives on the situation. Kanaka Maoli activist Andre Perez, a doctoral student at the University of Hawaici and a member of HauMĀNA, best articulated the issues at hand:

To be able to disagree is [one of] the fundamentals of academics. And yet they're telling us that we cannot disagree. But instead we must conform to what they think is proper behavior for Hawaiians. We cannot allow that to happen. We have to assert our right to free speech and understand that this is a bigger issue than free speech. The Mauna Kea issue has been ongoing for many years now. It's a very important part of Hawaiian politics and [the] Hawaiian struggle and we cannot allow the very institution that is at the core of this issue to suppress us right here in this so-called realm, this place of free thought and free speech. So we must always challenge and assert our right to be heard and to express our politics in ways that are dignified. ... We must kū'e [resist] and, as our Queen Lili'u said, we must 'onipa'a—we must stand firm. ${ }^{14}$

While Kailiehu reinscribed HauMĀNA's original statement of protest on the wall, Perez brought the deeper implication of the cover-up into full focus by drawing direct attention to the school newspaper's-and by extension the university's-attempt to erase Native voices:

Not only did they paint over our message but they put their "stamp" [ie, the advertisement] over ours... . They want to render us invisible people with no voices. We're not going to allow that to happen.

He also illuminated the glaring contradiction of Ka Leo's Hawaiian name:

The tragic irony is, look at the name of the newspaper that is silencing Hawaiians. $\mathrm{Ka} \mathrm{Leo,} \mathrm{The} \mathrm{Voice.} \mathrm{How} \mathrm{ironic} \mathrm{that} \mathrm{they} \mathrm{appropriate} \mathrm{and} \mathrm{adopt} \mathrm{our}$ Native language, our 'ōlelo Hawai'i [Hawaiian language], while simultaneously suppressing our voice. Erasing us under their layers of paint. 
Doctoral student Kamakaoka'ilima Seto-Long offered her own compelling testament of the events that unfolded and of the fortitude of the HauMĀNA organizers in the face of institutional obstruction:

We think it's important that we have a voice over what are our stolen Hawaiian lands. But that voice was suppressed because Ka Leo and Rob Reilly made it clear that it was not okay and that if we criticized the University of Hawai ${ }^{i} i$ that they would paint over it [ie, the mural]. They told us to take it down; we said, "No." They told us they would paint over it; we said that our message would go up no matter what. And they threatened to charge us with vandalism.

Kailiehu, the final person to speak, reflected on the experience of creating the mural alongside so many supporters from all walks of life and all ages (an estimated eighty people had shown up to help over the two-day period) and underscored the significance of art as a vehicle for Native voices to be heard. She declared:

Through art we can put this issue [ie, the issue concerning the desecration of Mauna-a-Wākea] to the forefront and allow the . . p public, not just a few people behind closed doors in a meeting, to decide whether or not the telescope should be built.

Her statement regarding the political power of art was made even more poignant by the printed message on her paint-splattered shirt: "Art is the absence of fear."

During the proceedings, the crowd had remained at a distance from the mural to give the speakers space to share their message. However, as soon as Kailiehu invited them to chalk their own sentiments of support on the wall, students, faculty, community members, and children quickly descended on the space. In the short span of fifteen minutes, the wall was transformed into an enormous visual petition, with messages calling for justice, solidarity, and the protection of the 'anina (figure 6). I recount some of those statements here:

"We will rise, survive, and be heard!!!"

"E Aloha 'Āina."

(Love the land.)

"Mai Poina!"

("Do not forget!")

"How much of our land are you gonna take UHм?"

"This Little Salmon woman from Northern Tutchone Territories supports

Kānaka Maoli.” 


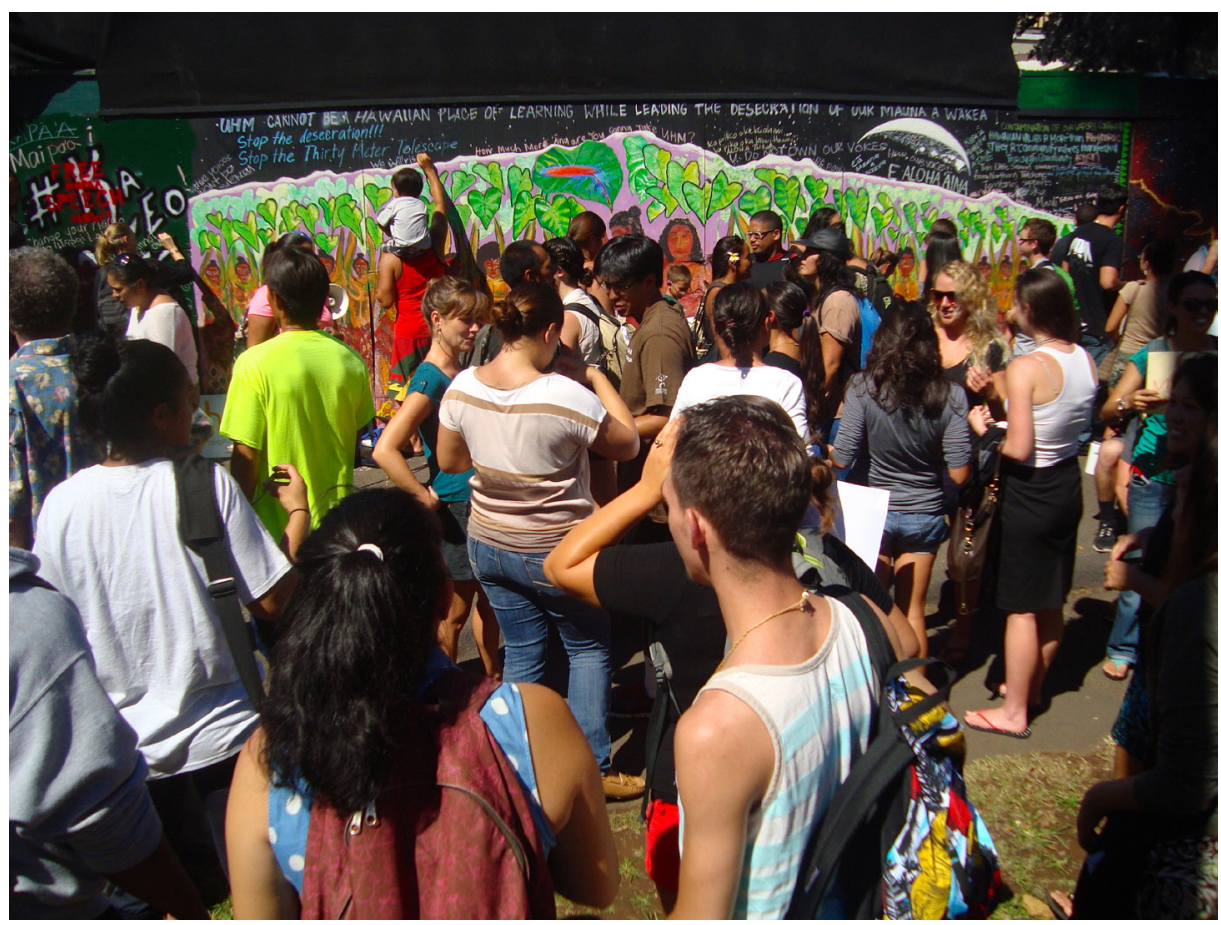

FIGURE 6 Supporters chalking their sentiments of solidarity on the Aloha 'Āina mural. Photograph by A Mārata Tamaira, 2013.

"Ka piko o ke kuahiwi, ka piko o ka lāhui Hawai'i. Aloha 'āina.”

("The navel of the mountain is the navel of the Hawaiian people. Love the land.")

"Tino Rangatiratanga!"

("Sovereignty!”)

In an important way, members of HauMĀNA linked their self-determination efforts of the present with those of the past by invoking the word "'onipa'a," which they interspersed in the red spray-painted message "FREE-'ONIPA'A-SPEECH NOW!" (figure 7). The rally continued with the assembly of supporters marching from the mural through UHM campus to Ka Leo's main office. As the procession advanced the crowd chanted, "Free speech now! Eō, Mauna Kea!" Several people carried upside-down Hawaiian flags, while many others bore signs with political messages (figure 8). On arriving at $\mathrm{Ka}$ Leo's headquarters, members of HauMĀNA presented the Board of Publications Chair Rebekah Car- 


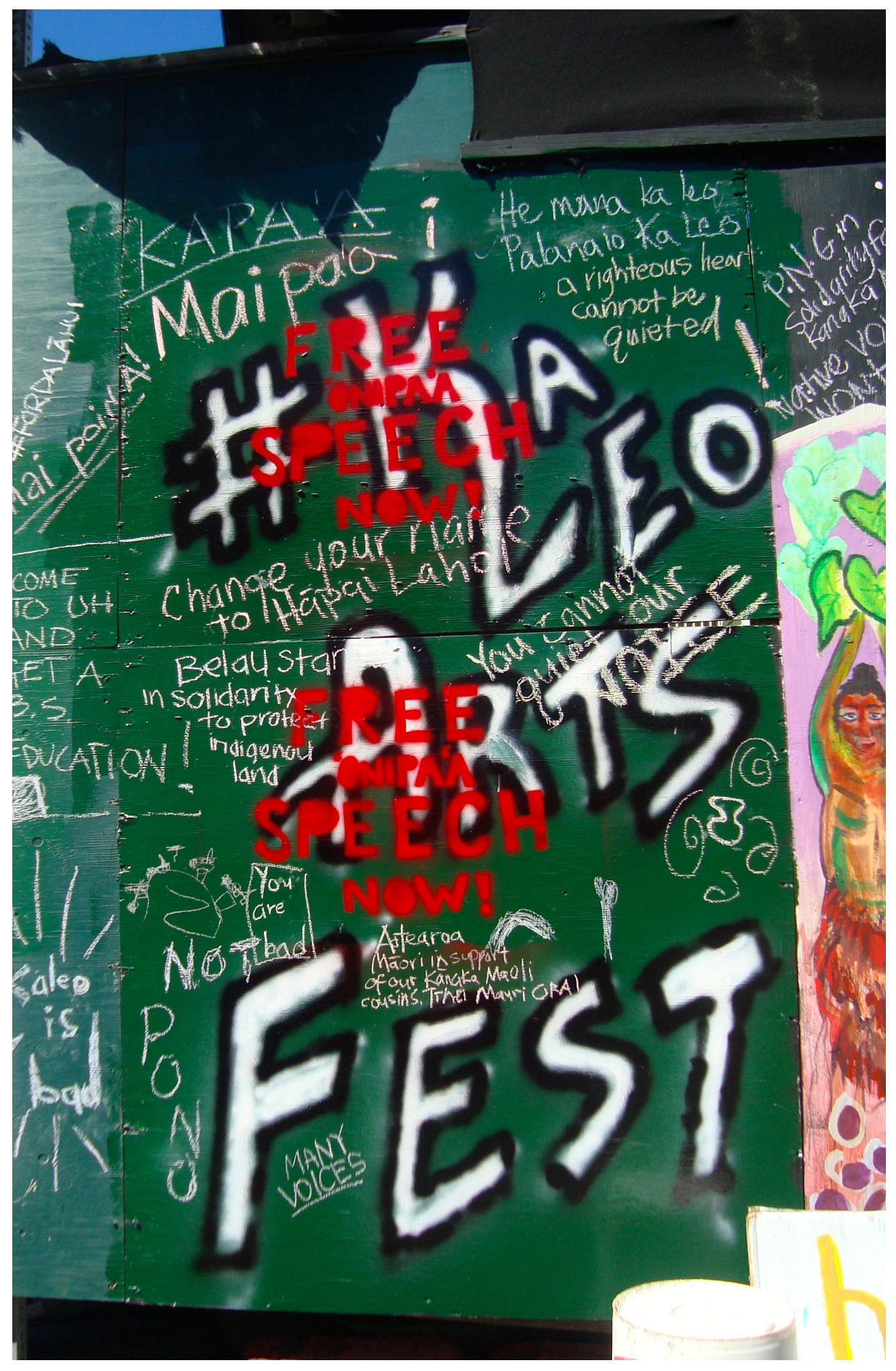

Figure 7 Detail of Aloha 'Āina mural. Photograph by A Mārata Tamaira, 2013. 


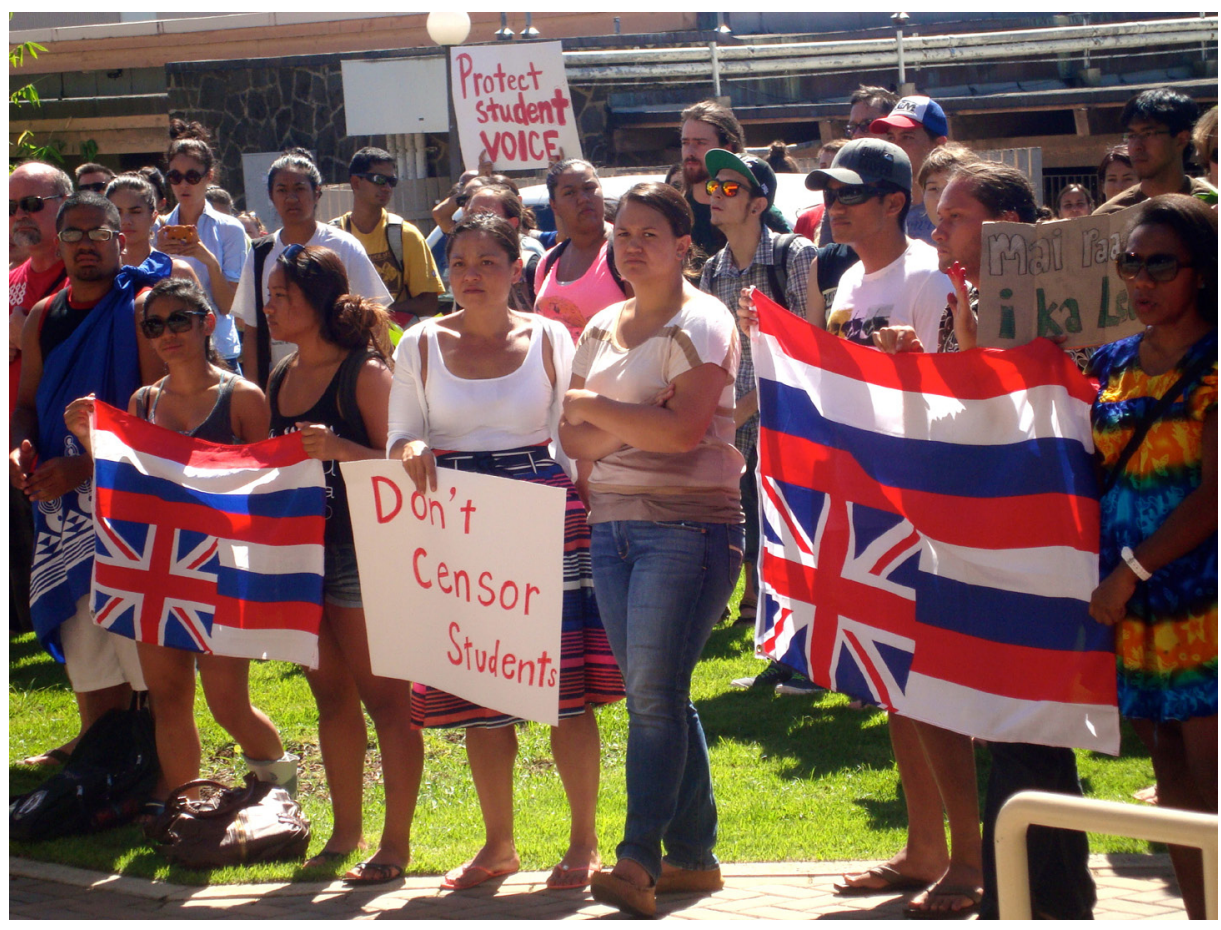

Figure 8 Aloha 'Āina mural rally protestors holding upside-down Hawaiian flags and signs while they wait outside Ka Leo's headquarters. Photograph by A Mārata Tamaira, 20I3.

roll with a letter of protest - the chief demand of which was that Ka Leo issue a public apology for censoring Kanaka Maoli voices-while protesters waited outside. ${ }^{15}$ As the rally came to a close, the crowd once again linked hands and a closing prayer in Hawaiian was offered to conclude the gathering.

\section{Breaking Down the Walls of Power}

With the mural wall now reclaimed by Kānaka Maoli and their supporters, the virtual wall of Facebook continued to be covered with posts that brought the issues surrounding the censorship of the mural and the ongoing desecration of Mauna-a-Wākea into high relief. One particular Facebook post by HauMĀNA illuminated the multiple shared and overlapping bastions of struggle that Kānaka Maoli occupy as they fight to simply have their voices heard: 
We brought the Mountain to UH Mānoa, we expressed our discontent with the University, just as the Hawai' $i$ island families fighting for the Mountain are and we were silenced by the university, just as the families of Hawai'i island are. ${ }^{16}$

The university's attempt at silencing of Native Hawaiian voices through the erasure of sections of the Aloha 'Āina mural must be understood as symptomatic of the ongoing oppression of Kānaka Maoli under US settler colonialism. Embedded in what Patrick Wolfe has termed the "logic of elimination," the essential characteristic of settler colonialism is that it "destroys to replace" (2006, 388 ). Let me recall Perez's statement above: "Not only did they paint over our message but they put their 'stamp' over ours."

In her insightful discussion of colonial strategies of erasure in Hawai'i, Karen Kosasa noted:

Settler colonialism in Hawai'i is composed of "acts of erasure." These "erasures" help to maintain the colonization of Native Hawaiians by creating a "settler imaginary" that continuously eliminates all references to colonialism. This process of erasure naturalizes the United States' illegal presence in Hawai' $i$. It also creates a perplexing situation where many settlers are unaware of the existence of colonialism and their participation in it. (Kosasa 2008, I96)

The destructive development of Mauna-a-Wākea in the name of corporate, scientific, and military interests is fundamentally rooted in the settler colonial project in Hawai'i. Wolfe has reminded us that the acquisition and control of Native lands is the prime motive of settler colonialism: "Territoriality is settler colonialism's specific, irreducible element" (2006, 388). As mentioned, the very lands that make up the mountain are part of the nearly two million acres that were seized from Hawaiians in I 898 when Hawai'i was illegally annexed to the United States. Mauna-a-Wākea is one of many sites where the indigenous struggle to reclaim stolen lands is being waged by Kānaka Maoli.

By erasing the mural's political message, the University of Hawai'i was in effect attempting not only to eliminate all references to the reality of colonialism in the Islands-specifically as it relates to the desecration of Mauna-a-Wākea-but to also conceal its own complicity in the settler colonial project through, among other things, its own participation in the abuse of those lands. Lisa Kahaleole Hall wrote, "Because colonization relies on forced forgetting and erasure, the need to bring the past forward into our consciousness is ongoing" $(2008,279)$. In the case of the Aloha 
'Āina mural, the past was brought forward in two ways: first by asserting and celebrating the ongoing connection between Kānaka Maoli and their ancestral lands, and second by exposing the colonial past as a system of oppression that continues to operate in Hawai'i to the present day. The mural was more than a work of art. It was a potent political challenge that unsettled and uncovered settler colonialism in Hawai'i and the ongoing hegemonic dominance of the United States.

More broadly speaking, the mural also served as a space in which indigenous supporters whose own peoples and lands abroad struggle under colonization could stand in solidarity with Kānaka Maoli. In his address during the rally, Kenneth Gofigan Kuper-a Chamorro graduate student from Guam, terrible swaths of which have been destructively transformed into a US military outpost—made this statement:

We stand here in solidarity with the Kānaka Maoli who are fighting to protect their sacred places. We need to realize that those of us who are not indigenous peoples of this land, this issue is not something we can simply walk on by.... This issue is our issue as well. As temporary dwellers here we have a responsibility to also do our part to help protect this land. ${ }^{17}$

In relation to Kosasa's keen observation that "many settlers are unaware of the existence of colonialism and their participation in it" (2008, I96), for those present at the rally whose ancestral home was not Hawai'iand I include myself here as a Māori woman who has lived in Hawai'i since $200 \mathrm{I}$-Kuper's exhortation for "temporary dwellers" or settlers to acknowledge their own responsibility to "do their part" in the Kanaka Maoli struggle served to perforate, even if briefly, the wall of epistemological ignorance so pervasive in Hawai' $i$.

\section{Postscript: From Protest to Celebration}

Less than ten days after the protest march, HauMĀNA organized another gathering, this time at Kamakakūokalani Center for Hawaiian Studies on the UHM campus-itself a bastion of Kanaka Maoli struggle and resistance-to celebrate the activism and solidarity that was displayed the previous week and to show, as stated on the events flyer, "what a Hawaiian place of learning really looks like." The event was titled Aloha 'Āina Arts Fest and it was strategically scheduled for 24 October, the same evening as the uHM-sponsored Ka Leo Arts Fest.

Aloha 'Āina Arts Fest was attended by approximately one hundred peo- 
ple and constituted a seamless weaving together of creative performance and indigenous political discourse. Kalani Flores-who, along with his wife Pualani Case and a larger coalition of Kānaka Maoli, environmentalists, and Big Island residents, has for decades been committed to stopping the desecration of Mauna-a-Wākea-made the journey from his home on the Big Island to O'ahu to share the latest developments in the struggle. He began his address by blowing into a pu (conch shell) three times. The first breath acknowledged the mountain, the second acknowledged the gathering of people, and the third acknowledged Wākea, Sky Father. I watched in transfixed wonder as the children who had previously been running around in raucous delight—my own daughter included—suddenly stopped and stood in stunned silence as the sound of the pu resounded in the air around them. The ritual blowing functioned as both a greeting and, more significantly, a clarion call to bring everyone to attention, even the youngest members present.

During the course of the evening, Kanaka Maoli poets and spokenword artists arrived on the stage to share their political perspectives. Poet David Keali'i underscored the fundamental differences between Western and Hawaiian understandings of Mauna-a-Wākea in his poem "For Mauna Kea”:

You act as if your worldview is the only one that matters, if you only asked we would have told you what we see in the night:

patterns carved into the sky's dark calabash

so voyages can be made

to Kahiki, Hawaiki, Pulotu-

the thousand islands sewn

the length of limitless canoes.

But you have decided to build

and build into the heights

where Papa and Wākea meet. ${ }^{18}$

The competing visions and understandings of Mauna-a-Wākea as observed by the poet can be understood in relation to what Māori scholar and activist Moana Jackson described in a 2004 presentation he gave at the University of Hawai'i as the collision of two realities: 
the reality of tradition and history, which shaped our identity [as indigenous people] and the reality of colonization, which has sought and still seeks to destroy it, to reconceptualize it, to fit it within a paradigm, which is not ours. (University of Hawai'i 2004)

Such destructive and reconceptualizing tactics as used by the United States in Hawai' $i$ to undermine and erode Native identity have entailed the longstanding assault on places across the Islands held sacred by Kānaka Maoli, including but not limited to their ancestral mountain Mauna-a-Wākea. As the mural and subsequent protest rally and arts festival revealed, however, such assaults do not go unchallenged by Native stewards. Observed Keali'i at the end of his poem:

\author{
But arrogance \\ must always be checked. \\ We will never consent, \\ we will always resist \\ your bladed \\ destruction across \\ the 'āina.
}

While the performances and presentations on stage were the focal point, behind the scenes Kailiehu and a retinue of assistants created works of art in the form of T-shirts that were screen-printed with a monochromatic image of the mural and a caption that read, "Eō Mauna A Wākea. Sacred Mountain True Hawaiian Place of Learning." When considered together, the artwork, poetry, and political testimonies featured during the event demonstrate how Kanaka Maoli aesthetic activism and political engagement converge to produce a multipronged discourse of resistance. For over one hundred years, Kānaka Maoli have been bringing the symbolic power of the creative arts to bear on their struggle to reclaim and protect their homeland. As I hope I have made clear throughout this writing, that practice continues to be carried out today with the same vigor, conviction, and commitment.

\title{
ReClaiming AND TRANSFORMING
}

In this article, I have offered two case studies of indigenous art with a specific focus on public murals to illuminate the ways Kanaka Maoli artists 
use the walls of the built environment as semiotic slates to raise political consciousness and articulate an indigenous-centered, decolonizing frame of self-representation. The two mural projects I have examined serve as important sites of ethical and aesthetic activism that assert Kanaka Maoli sovereignty through themes of cultural continuity, environmental stewardship, and ongoing ancestral connections. They draw on a range of culturally informed symbols and imagery and are grounded in a Hawaiian philosophy of knowing.

In Hawai'i, where Native lands have been converted into commodities of colonial enterprise, the murals-all of which are located on seized Hawaiian lands-constitute a critical reclaiming and reconversion of space from colonial possession to Kanaka Maoli patrimony. In this way, public art offers Kānaka Maoli the opportunity to "influence the shape and content of their surroundings" in ways that are both material and symbolic (Cockcroft, Weber, and Cockcroft 1977,96$)$. However, such a reclaiming of space, as we have seen, does not go unchallenged, as was the case with the Aloha 'Áina mural, where the political message was crudely censored. The silencing underscores in a clear way the degree to which Kānaka Maoli continue to struggle to have their voices heard in settler Hawai' $i$, whether in the halls of government or on the walls of a university campus.

Nevertheless, if, as Lisa Kahaleole Hall wrote, "colonization relies on a forced forgetting and erasure" $(2008,279)$, then the murals in this article recall and expose colonialism in Hawai'i through strategies that range from covert allusion to undisguised castigation. Here, public art provides an ideal forum for presenting indigenous concerns and grievances to the wider citizenry of Hawai'i, many of whom are unaware of colonialism or are at the very least ignorant of the conditions under which Kānaka Maoli must live. The murals reflect a Kanaka Maoli reality and in so doing "function to unscrew the power of the colonizing force by creating a new consciousness" (Trask I999, 90).

And it is perhaps in the work that murals do to create a new consciousness that they make their most lasting mark. Artwork in clay or bronze, on paper or canvas, can last for decades and even centuries if properly cared for. However, murals are by nature temporary: the paint by which they are created is exposed to the elements of rain, wind, and light, and the very walls on which they appear are in constant peril of the developer's wrecking ball. While the wall on which Ola Ka Wai, Ola Ka Honua is featured is safe for now, the rapid development of Honolulu means that it will always 
be at risk of destruction. Further, several weeks after the Aloha 'Āina Arts Fest, I revisited the mural and was saddened to see that all of the chalked sentiments of solidarity had been removed, this time not through censorship but by the transforming elements of wind and rain. What remained was the ghostly palimpsest of barely legible text that had at one time been so outrageously visible. I felt disheartened until I realized that murals are perhaps less about the products themselves and more about the collective experience of creating the work of art and bearing witness to its message. In relation to Ola Ka Wai, Ola Ka Honua and the Aloha 'Áina mural, the artists and the public were transformed in profound and, one might hope, lasting ways-conscientized, as Paulo Freire would say, raised to new levels of awareness. Yes, every wall is a gate. But it is only in comprehending the message on the wall that the gate will open.

I EXTEND My DeEPest thanks to artists John "Prime" Hina, Haley Kailiehu, and Estria Miyashiro for their willingness to share their valuable insights with me during fieldwork I conducted on the public wall art projects they were involved with. I am also appreciative of Paula Ota, who graciously granted me permission to use two photographs she took of Ola Ka Wai, Ola Ka Honua. Finally, I acknowledge with gratitude two anonymous reviewers who provided thoughtful and discerning feedback that served to enhance the final version of this paper. This article is a revised chapter taken from my doctoral thesis (Tamaira 2015). Research for this paper was carried out with the financial assistance of the Australian National University Vice-Chancellor's Scholarship for Doctoral Study and support from the Australian Research Council Laureate Project Engendering Persons, Transforming Things: Christianities, Commodities, and Individualism in Oceania.

\section{Notes}

I This excerpt from Emerson's I844 journal entry is reproduced in Rosenwald 2010, 239.

2 While the west face of the Berlin Wall was covered in graffiti, such aesthetic expressions were suppressed by the threat of deadly force on the east face.

3 I am grateful to Raukura Roa for her translation of the mural's title.

4 The other ten sites where WaterWrites murals have so far been produced include Los Angeles, California; Oakland, California; Gaza Strip, Palestine; Palawan, Philippines; Usulután, El Salvador; Orleans, California; Bogota, Colombia; 
Cape Town, South Africa; Phoenix, Arizona; and Vancouver, British Columbia. For more information on the separate projects, go to http:/www.estria.org/water -writes/

5 The other artists included Vogue TDK, Katch, Rival, Krush TWS, Escape, Dmize2 25, Krush BS, Eukarezt, Bieste, Quest, Trax, Ohana, Wyte, SMK, CKaweeks, Looks, Sierra Dew, and Noize22.

6 For a more in-depth discussion of water rights issues in Hawai'i, see, eg, Sproat 2010.

7 The other three streams are Waihe'e, Waikapū, and Waiehu. The waters are under the control of Wailuku Agribusiness, which leases the resource to agricultural businesses such as Hawaiian Commercial and Sugar Company and Maui Pineapple Company.

8 In a more literal sense, this saying means, "Flowers thrive where there is water, as thriving people are found where living conditions are good." See Pukui I $983, \mathrm{I} 8,237$.

9 It is also important to consider that as well as deploying images of indigenous leaders in their wall art, indigenous artists also appropriate images of notable nonindigenous figures whom they perceive as representing the struggle for social justice, self-determination, and indigenous sovereignty. Such figures include but are not limited to Bob Marley, Bruce Lee, Nelson Mandela, and Martin Luther King Jr. For an in-depth account of this creative mode of appropriation in the Aotearoa/New Zealand context, see Mallon 2012.

Io The song was written by Ellen Kekoaohiwaikalani Wright Prendergast, a friend of Queen Lili'uokalani.

I I Comprising UHM students, HauMĀNA serves as the student branch of MANA (Movement for Aloha no ka 'Āina), “a movement-building organization, established to achieve [Native Hawaiian] independence and social justice through direct action, political education, economic development, international diplomacy, and public advocacy, with a cultural and spiritual foundation." See HauMĀNA's Facebook page at https://www.facebook.com/haumanastudentmovement.

I 2 Those countries include Canada, France, the United Kingdom, Japan, Argentina, Australia, Brazil, Chile, Netherlands, Taiwan, and the United States.

I 3 The destruction of a six-foot-high lele (wood altar) by vandals in 2006 underscored the challenges Kānaka Maoli face concerning the practice of their culture and religious rites on the mountain.

I 4 Special thanks to Doug Matsuoka for providing me with video footage he took of the rally, which facilitated transcription of the $\mathrm{I}_{3}$ October speeches. This and the following four statements were transcribed from the video recording.

I 5 HauMĀNA leadership eventually received two formal letters of apology in response to their letter of protest, one from Bonnyjean Manini, the Interim Direc- 
tor of the Office of Student Life and Development, and the other from Rebekah Carroll on behalf of the University of Hawai'i's Board of Publications.

I 6 This statement is from HauMĀNA's Facebook Page.

I7 This statement was transcribed from video footage of the I $3_{3}$ October speeches at the rally.

I 8 The unpublished poem is reproduced here with the author's kind permission.

References

Baker, Frederick

2005 The Berlin Wall. In Borders and Border Politics in a Globalizing World, edited by Paul Ganster and David E Lorey, 2 I-49. Lanham, MD: SR Books.

Brown, Wendy

2010 Walled States, Waning Sovereignty. New York: Zone Books.

Cockcroft, Eva, John Weber, and Jim Cockcroft

I977 Toward a People's Art: The Contemporary Mural Movement. New York: E P Dutton \& Co, Inc.

Dowell, Kristin L

20I3 Sovereign Screens: Aboriginal Media on the Canadian West Coast. Lincoln: University of Nebraska Press.

Estria Foundation

2012 \#Water Writes Honolulu Mural Project. YouTube. Uploaded I2 February. www.youtube.com/watch? $\mathrm{v}=\mathrm{nAeYOrZbJtA}$ [accessed I4 June 20I6]

Hall, Lisa Kahaleole

2008 Strategies of Erasure: US Colonialism and Native Hawaiian Feminism. American Quarterly 60 (2): 273-280.

Kaire-Melbourne, Kimiora

20I 5 Artists Owen Dippie and Tame Iti Complete Tāneatua Mural. Māori Television, 4 November. http://www.maoritelevision.com/news/ galleries/artists-owen-dippie-and-tame-iti-complete-taneatua -mural-o [accessed 20 June 2016]

Kosasa, Karen K

2008 Sites of Erasure: The Representation of Settler Culture in Hawai'i. In Asian Settler Colonialism: From Local Governance to the Habits of Everyday Life in Hawai' $i$, edited by Candace Fujikane and Jonathan Y Okamura, I95-208. Honolulu: University of Hawai'i Press. 
LaDuke, Winona

2005 Recovering the Sacred: The Power of Naming and Claiming. Cambridge, mA: South End Press.

Lefebvre, Henri

I976 Reflections on the Politics of Space. Translated by Michael J Enders. Antipode 8 (2): 30-37.

Lewisohn, Cedar

2008 Street Art: The Graffiti Revolution. New York: Abrams.

Mallon, Sean

2012 Urban Art and Popular Culture. In Art in Oceania: A New History, edited by Peter Brunt, Nicholas Thomas, and Sean Mallon, 440-465. London: Thames \& Hudson Ltd.

Matsuoka, Doug

20I3 Video recording of Aloha 'Āina mural rally, October. In videographer's private files.

Moriwake, Isaac, and Kapua Sproat

20I I Restoring Water Rights in Hawai'i. Podcast available via Earth Justice website: http://earthjustice.org/audio/restoring-water-rights-in -hawaii; transcript available at http://earthjustice.org/features/ campaigns/down-to-earth-hawai-i-water [accessed I4 Nov 20I3]

Nordyke, Eleanor C, and Martha H Noyes

I993 Kaulana Nā Pua: A Voice for Sovereignty. The Hawaiian Journal of History 27:27-42.

Ortner, Sherry B

I973 On Key Symbols. American Anthropologist 75 (5): I338-г 346.

Puhipau and Joan Lander, producers and directors

2006 Mauna Kea: Temple Under Siege. DVD, 57 minutes. Nā‘ālehu, HI: Nā Maka o Ka 'Āina.

Pukui, Mary Kawena

I983 'Ōlelo No'eau: Hawaiian Proverbs and Poetical Sayings. Bernice P Bishop Museum Special Publication 7I. Honolulu: Bishop Museum Press.

Raheja, Michelle H

2010 Reservation Reelism: Redfacing, Visual Sovereignty, and Representations of Native Americans in Film. Lincoln: University of Nebraska Press.

Rickard, Jolene

I995 Sovereignty: A Line in the Sand. Aperture I39 (summer): 5I-54.

Rosenwald, Lawrence, editor

2010 Ralph Waldo Emerson: Selected Journals, I84I-I877. New York: Library of America. 
Silberman, Marc, Karen E Till, and Janet Ward, editors

$20 \mathrm{I} 2$ Walls, Borders, Boundaries: Spatial and Cultural Practices in Europe. New York: Berghahn Books.

Sproat, D Kapua'ala

20 Io Water. In The Value of Hawai' $i$ : Knowing the Past, Shaping the Future, edited by Craig Howes and Jonathan Kay Kamakawiwo'ole Osorio, I 87-I94. Honolulu: University of Hawai'i Press.

Tamaira, A Mārata Ketekiri

2OI5 Frames and Counterframes: Envisioning Contemporary Kanaka Maoli Art in Hawai'i. PhD dissertation, The Australian National University.

Trask, Haunani-Kay

I994 Light in the Crevice Never Seen. Corvallis, OR: Calyx Books.

I999 From a Native Daughter: Colonialism and Sovereignty in Hawai'i. Honolulu: University of Hawai'i Press.

Tsinhnahjinnie, Hulleah J, and Veronica Passalacqua, editors 2006 Our People, Our Land, Our Images: International Indigenous Photographers. Davis, CA: The Regents of the University of California.

University of Hawai'i

nd Achieving Our Destiny: The University of Hawai'i at Mānoa 20I I20I5 Strategic Plan. Honolulu: University of Hawai'i-Mānoa. https://manoa.hawaii.edu/strategicplan/vision-20I I-20I 5/pdf/ achieving-our-destiny.pdf [accessed I4 June 20I6]

2004 Reality, Identity, and Eating $M$ and Ms. DVD, 30 minutes. Produced by the University of Hawai'i. Video recorded presentation delivered at the United Nations Global Seminar ist Hawai'i Session, Negotiating Pacific Identities: Ethnicity, Encounters, and Self-Determination, University of Hawai'i-Mānoa, Honolulu, I9-22 March.

Winpenny, Jamie

20I3 The Uncertain Future of Mauna Kea. Big Island Weekly, 26 June.

Wolfe, Patrick

2006 Settler Colonialism and the Elimination of the Native. Journal of Genocide Research 8 (4): 387-409.

\section{Abstract}

Since the illegal overthrow of the Hawaiian Kingdom in I 893 and the subsequent fraudulent annexation of the Islands by the United States in I 898, Native Hawaiians (Kānaka Maoli) have vigilantly contested US colonialism in Hawai'i and have 
resolutely sought to defend and affirm their existence as the still-sovereign people of their homeland through political, legal, cultural, and artistic means. While the first three kinds of indigenous resistance have been well documented in numerous books, journal articles, and theses, there remains a largely unexplored field of academic enquiry concerning the role of contemporary Kanaka Maoli art within this milieu. This article seeks to redress this shortfall by critically analyzing how Hawaiian artists use the discrete discursive space of public walls as semiotic slates to both affirm Native sovereignty and contest US colonialism. I explore sovereign artistic intervention as it is manifested in two wall projects: Ola $\mathrm{Ka}$ Wai, Ola Ka Honua by graffiti writers John "Prime" Hina and Estria Miyashiro and the Aloha 'Āina mural by students, faculty, and community members at the University of Hawai'i-Mānoa. As I show, these projects illuminate the power of public art to galvanize not only indigenous communities but also the broader public around contemporary and ongoing indigenous political concerns in Hawai'i.

KEYWORDs: graffiti writing, indigenous public art, murals, Native Hawaiians, Hawai'i, visual sovereignty, aesthetic activism 